\title{
Áherslur stjórnenda árangursríkra fyrirtækja og hugmyndafræði pjónandi forystu
}

\author{
Sigurbjörg Hjálmarsdóttir og Sigrún Gunnarsdóttir ${ }^{1}$
}

\begin{abstract}
Ágrip
Síðustu árin hefur orðið viðhorfsbreyting til forystu og stjórnunar í takt við nýjar rannsóknir um að aukið vægi leiðsagnar, jafningjabrags og sameiginlegrar framtíðarsýnar geti skilað betri árangri gagnvart starfsfólki og fyrirtækinu í heild samanborið við fyrirskipanir með áherslu á völd fárra. Fáar rannsóknir fjalla um hvaða pættir einkenni fyrirtæki sem ná góðum árangri en meðal kannana á pessu sviði er könnun Verzlunarmannafélags Reykjavíkur (VR) um fyrirtæki ársins. Pjónandi forysta byggir á sjálfstæði starfsfólks, skýrri framtíðarsýn, ábyrgðarskyldu, hlustun og stuðningi stjórnenda. Markmið pessarar rannsóknar er að kanna áherslur stjórnenda og leiðtoga hjá fyrirtækjum sem eru í hópi fyrirtækja sem endurtekið hafa fengið viðurkenninguna „fyrirmyndarfyrirtæki“ hjá VR. Jafnframt er markmiðið að kanna hvort og pá hvernig áherslur peirra endurspegli hugmyndafræði pjónandi forystu. Framkvæmd var eigindleg rannsókn og tekin viðtöl við sjö stjórnendur Fyrirmyndarfyrirtækja VR til að varpa ljósi á mikilvægar áherslur leiðtoga fyrir árangur fyrirtækjanna. Greind voru lykilatriði í stjórnun og forystu viðmælenda og dregnar fram áherslur sem skipta máli fyrir árangur fyrirtækjanna og koma fram í premur pemum. Fyrsta pemað er stjórnun sem stuðningur og samspil ólíkra hlutverka, annað pemað er hagur starfsmanna og jafningjatengsl leiðtoga og starfsmanna og priðja pemað er framtíðarsýn og virk upplýsingagjöf. Niðurstöður rannsóknarinnar eru í takt við niðurstöður nýrra rannsókna um mikilvæga pætti leiðtoga sem tengjast árangri og ánægju starfsfólks. Pá sýna niðurstöður að áherslupættir í stjórnun viðmælenda eru í takt við megineinkenni hugmyndafræði pjónandi forystu og styðja fyrri rannsóknir um tengsl pjónandi forystu við starfsánægju og árangur skipulagsheilda. Rannsóknarniðurstöður gefa áhugaverða innsýn í áherslur stjórnenda sem náð hafa sérstökum árangri og hvernig pær endurspegla hugmyndafræði pjónandi forystu. Rannsóknin er framlag til pekkingar á sviði pjónandi forystu og hefur hagnýtt gildi fyrir fyrirtæki, stjórnendur og starfsmenn.
\end{abstract}

1 Sigurbjörg Hjálmarsdóttir er viðskiptafræðingur hjá Ernst \& Young ehf. Netfang: sigurbjorgh12@bifrost. is. Sigrún Gunnarsdóttir er dósent við Viðskiptafræðideild Háskóla Íslands og Viðskiptafræðideild Háskólans á Bifröst. Netfang: sigrungu@hi.is.

This work is licensed under a Creative Commons Attribution 4.0 License.

DOI: https://doi.org/10.24122/tve.a.2018.15.2.7

(C) Tímarit um viðskipti og efnahagsmál

www.efnahagsmal.is 


\begin{abstract}
Current attitudes towards leadership and management are in line with new research about how increased focus on coaching, culture of equals and common foresight can lead to better outcomes for staff and business in general when compared to focus on giving orders and the power of few. Limited research is available on characteristics of successful companies but among surveys in this field is the survey conducted by labor union Verzlunarmannafélag Reykjavíkur (VR) about Company of the year. Servant leadership builds on freedom of staff members, clear vision and accountability and focus on listening and support of managers. The goal of this study is to investigate the emphasis of managers and leaders of companies which are among campanies that have repeatedly received recognition as an "exemplary company" by VR. Also, the goal was to investigate if and how their emphasis reflects the philosophy of servant leadership. A qualitative study was conducted by interviewing seven managers of VR's exemplary companies to shed light on important management elements for success of the company. Key elements of respondents' management and leadership were analyzed and elements important for the success of their companies reflected in three themes. The first theme is management as support and the balance of different roles, the second theme is staff interests and relationship of equals between leaders and staff and the third theme is foresight and active flow of information. Findings are in line with previous research about important leadership qualities linked to job satisfaction and success. Study findings also show that the management emphasis of participants reflect important elements of the philosophy of servant leadership and support previous research about the link between servant leadership, job satisfaction and business success. The findings provide interesting insight into qualities of successful managers and how they reflect servant leadership. The research contributes to knowledge in the field of servant leadership and has practical value for companies, management and staff.
\end{abstract}

JEL flokkun: M1, M2

Lykilorð: Pjónandi forysta; árangursrík fyrirtæki; stjórnendur; starfsmenn; starfsánægja.

Keywords: Servant Leadership; exemplary companies; managers; employees; job satisfaction.

\title{
The key characteristics of business managers in exemplary companies and the philosophy of servant leadership
}

\section{Inngangur}

Síðustu árin hefur orðið ákveðin viðhorfsbreyting til forystu og stjórnunar innan fyrirtækja í takt við nýjar rannsóknir sem gefa sterkar vísbendingar um að aukið vægi leiðsagnar og styðjandi samskipta geti skilað betri árangri en fyrirskipanir og samskipti sem byggja á hefðbundnum valdapíramída (Goleman, 2013). Rannsóknir sýna einnig að yngsta kynslóðin á vinnumarkaði nú, púsaldarkynslóðin (e. millennials), leggur áherslu á að hafa ákveðinn tilgang og markmið með vinnu sinni umfram pað að hafa megin áherslu á að afla tekna. Pá sýna rannsóknir að pessi kynslóð aðhyllist stjórnendur sem nota aðferðir pjálfara umfram skipanir, metur starfsfólk sem einstaklinga og starfsmenn, veitir peim skilning og byggir upp styrkleika peirra (Clifton, 2016).

Próun á vinnumarkaði undanfarin ár sýnir að víða um lönd er óánægja starfsmanna vaxandi vandamál sem getur haft áhrif á árangur fyrirtækja og stofnana (Gallup, 2016). Rannsóknir benda endurtekið til pess að vinnstaðamenning, félagslegur stuðningur á vinnustað og áherslur leiðtoga hafa afgerandi tengsl við ánægju starfsmanna og starfsgetu peirra (Belias og Koustelios, 2014; Sigrún Gunnarsdóttir og Birna Gerður Jónsdóttir, 
2013). Í ljósi pessa og einnig miðað við að árangur og framleiðni fyrirtækja hér á landi er minni en almennt gerist í nágrannalöndum (McKinsey og Company, 2012) er áhugavert og mikilvægt að varpa ljósi á árangursrík fyrirtæki hér á landi og rýna í áherslur og aðferðir stjórnenda og leiðtoga í pessum fyrirtækjum.

Árleg könnun Verzlunarmannafélags Reykjavíkur (VR) um Fyrirtæki ársins veitir áhugaverðar upplýsingar um atriði sem einkenna árangursrík fyrirtæki hér á landi. Í könnun VR er varpað ljósi á pætti sem skipta máli fyrir líðan starfsfólks og viðhorf til stjórnenda og fyrirtækis svo sem starfsanda, samskipta, launakjör, vinnuskilyrði, sveigjanleika á vinnutíma, sjálfstæði í starfi, áhrif starfsmanna á starf sitt, ánægju og stolt starfsmanna af vinnustað sínum og ímynd fyrirtækisins (VR, 2016a).

Nýjar rannsóknir sýna að styðjandi stjórnunaraðferðir og forysta sem einkennist af skýrri sýn á markmið og góðum samskiptum tengist góðum árangri bæði gagnvart líðan starfsfólks (Belias og Koustelios, 2014; Zwingmann, Wegge, Wolf, Rudolf, Schmidt og Richter, 2014) og í sambandi við árangur fyrirtækja og stofnana (Aronsson o.fl., 2017; Coetzer, Bussin og Geldenhuys, 2017). Pá sýna rannsóknir að hófsemi og auðmýkt stjórnenda með pjónandi forystu er mikilvæg til að ná árangri fyrir starfsfólk og hagnað fyrirtækja (Hayes og Comer, 2010; Sousa og Dierendonck, 2017). Pjónandi forysta er í flokki forystuog stjórnunaraðferða sem einkennast af áðurnefndum áherslum og fram hefur komið að pjónandi forysta í fyrirtækjum tengist góðum árangri (van Dierendonck, 2011). Undanfarin ár hefur verið birtur fjöldi rannsókna og yfirlitsgreina sem lýsa megineinkennum pjónandi forystu (van Dierendonck, 2011; Parris og Peachy, 2012), meta vægi pjónandi forystu í fyrirtækjum og stofnunum, til dæmis samkvæmt mati starfsfólks (van Dierendonck og Nuijten, 2010; Sigrún Gunnarsdóttir og Birna Gerður Jónsdóttir, 2013) og meta tengsl pjónandi forystu og ýmissa útkomupátta sem snerta t.d. líðan og árangur starfsmanna, árangur teymisvinnu og árangur skipulagsheilda (Coetzer, Bussin og Geldenhuys, 2017; Parris og Peachy, 2012). Hins vegar eru ekki fyrirliggjandi, svo kunnugt sé, rannsóknir sem ná til fyrirtækja sem sýnt hafa sérstaklega góðan árangur par sem áherslur stjórnenda eru skoðaðar í ljósi pjónandi forystu.

Í ljósi árangurs Fyrirmyndarfyrirtækja VR er áhugavert að skoða hvaða áherslur stjórnenda og leiðtoga í slíkum fyrirtækjum, að peirra mati, skila hinum góða árangri og jákvæðu viðhorfi starfsfólks. Vegna sterkra vísbendinga um að góður árangur tengist pjónandi forystu er einnig áhugavert að kanna hvort áherslur stjórnenda og leiðtoga í fyrirtækjum sem flokkast til Fyrirmyndarfyrirtækja VR endurspegli pjónandi forystu. Með eigindlegri nálgun er mögulegt að fá innsýn í mikilvæga reynslu og viðhorf stjórnendanna. Í rannsókninni er varpað ljósi á stjórnunaraðferðir og áherslur leiðtoga í sjö af peim fyrirtækjum sem endurtekið hafa lent á lista Fyrirmyndarfyrirtækja VR undanfarin ár. Pá er einnig greint hvort og pá hvernig pessar áherslur endurspegli pjónandi forystu samkvæmt áherslum fræðimanna par um. Til að ná fram markmiðum rannsóknarinnar er leitað svara við eftirfarandi rannsóknarspurningum:

\section{Hverjar eru áherslur stjórnenda í árangursríkum fyrirtækjum sem flokkast til Fyrirmyndarfyrirtækja VR? Endurspegla pessar áherslur hugmyndafræði pjón- andi forystu og hvernig pá?}

Tekin voru viðtöl við leiðtoga og stjórnendur hjá sjö fyrirtækjum sem skarað hafa fram úr og endurtekið fengið viðurkenninguna Fyrirmyndarfyrirtæki hjá VR undanfarin ár. Leitast er við að fá innsýn í pætti sem einkenna forystu og stjórnun hjá pessum leiðtogum og kannað hvort og hvernig peir pættir endurspegli hugmyndafræði pjónandi forystu.

Fjallað er um hugmyndafræði pjónandi forystu og rannsóknir sem meta tengsl pjónandi forystu og árangurspátta skipulagsheilda. Pá er aðferðum rannsóknarinnar lýst, fjallað um pætti sem tilheyra könnun á Fyrirmyndarfyrirtækjum VR., greint frá niðurstöðum rannsóknarinnar og um pær fjallað í ljósi fyrri rannsókna. 


\section{Fræðilegur hluti}

\subsection{Pjónandi forysta}

\subsubsection{Hugmyndafræði pjónandi forystu}

Litið er á pjónandi forystu sem hugmyndafræði frekar en ákveðna kenningu eða ákveðinn forystustíl einkum í ljósi pess að bjónandi leiðtogar nýta ýmsar kenningar og stíla sem hæfa aðstæðum hverju sinni og uppfylla gildi og viðmið hugmyndafræðinnar (Blanchard, 2018; Prosser, 2010). Grundvöllurinn er mannúð, sameiginleg ábyrgðarskylda og jafningjabragur sem lýsir sér einkum í pví að leiðtoginn lítur á sig fremstan meðal jafningja (Greenleaf, 2008; Sigrún Gunnarsdóttir, 2011).

Helstu eiginleikar pjónandi forystu birtast í einlægum áhuga leiðtogans á högum annarra, innri styrk hans og skýrri framtíðarsýn (Sigrún Gunnarsdóttir, 2011). Pegar litið er til rita upphafsmanns hugmyndarinnar um pjónandi forystu, Robert K. Greenleaf, má sjá að pjónandi forysta einkennist af premur meginstoðum, p.e. 1) einlægur áhugi á hagsmunum annarra og hugmyndum; 2) innri styrkur leiðtogans sem hefur næmi, vitund og sjálfspekkingu og 3) framtíðarsýn og hugsjón sem afmarkar ábyrgðarskyldu (Sigrún Gunnarsdóttir, 2011). Petta priggja pátta líkan er í samræmi við sjö grunnpætti sem einkenna pjónandi forystu samkvæmt rannsóknum Dirk van Dierendonck (2011), p.e. að efla og proska samstarfsfólk, auðmýkt, falsleysi, opnar viðtökur, stefnumörkun og ráðsmennska (samfélagsleg ábyrgð). Líkanið er einnig í takt við niðurstöður fræðilegs yfirlits Coetzer, Bussin og Geldenhuys (2017) og líkan Laub (2010) um einkenni og hæfni pjónandi leiðtoga, p.e. heilindi, auðmýkt, umhyggja, ábyrgðarskylda, hugrekki, að gæta hagsmuna annarra, heiðarleiki, hlustun, efling, samfélagsleg ábyrgð, að geta myndað tengsl og sannfærandi sýn. Einkenni pjónandi leiðtoga samkvæmt pessum fræðimönnum má flokka í prjá meginpætti: Fyrsti pátturinn snýr að fylgjendum leiðtogans sem hann sýnir einlægan áhuga varðandi hagsmuni og hugmyndir og leitast við að efla og proska samstarfsfólk, sýnir pví viðurkenningu og tekur opnum örmum, metur fólk og skapar sterk tengsl. Annar pátturinn snýr að leiðtoganum sjálfum og viðleitni hans til að efla innri styrk, leita sjálfspekkingar, sjálfsproska og hugrekki og leiðtoginn gengur fram í auðmýkt og falsleysi. Priðji pátturinn snýr að framtíðinni og umhverfi leiðtogans og felst í hugsjón, skýrri sýn á tilgang, stefnu og framtíð sem birtist í ábyrgðarskyldu gagnvart starfsfólki, skipulagsheild sem og samfélagi og umhverfi par sem leiðtoginn er góð fyrirmynd, tekur frumkvæði og deilir forystu. Pættirnir prír eru samofnir og tengja hina tvíhliða hugmynd um pjóninn sem verður leiðtogi. Líta má á tvo fyrstu pættina sem pjónandi vídd leiðtogans sem felur einkum í sér viðhorf og samskipti og priðji pátturinn svarar til forystuvíddarinnar sem snýr einkum að stefnu, áætlunum og aðgerðum (Blanchard, 2018).

Í upprunalegu riti Greenleaf (2008) má sjá að hugmyndir hans um pjónandi forystu eru nátengdar ýmsum grunnhugmyndum um stjórnun, t.d. hugmyndum Drucker (1999) um pekkingarstarfmenn og hvatningu, hugmyndir Herzberg (1987) um innri starfshvöt og hugmyndir Goleman um tilfinningagreind (1995) og um félagsgreind (2006). Mörg rit hafa verið birt undanfarin ár sem fjalla um pjónandi forystu, tækifærin sem felast í hugmyndinni og um pætti sem aðgreina og tengja pjónandi forystu við aðrar hugmyndir um forystu (t.d. Sendjaya, Sarros og Santora, 2008; van Dierendonck, 2011). Til dæmis hefur í gegnum árin verið birt y firlit um fræðilegan samanburð pjónandi forystu og umbreytandi forystu (e. transformational leadership). Samanburðurinn hefur sýnt að раð sem einkum aðgreinir hugmyndirnar tvær er að í umbreytandi forystu er útgangspunkturinn að mæta pörfum skipulagsheildarinnar en í pjónandi forystu er útgangspunkturinn að mæta pörfum starfsfólks og pannig er markmiðum skipulagsheildarinnar náð (Liden, Wayne, Zhao og Henderson, 2008; Parolini, Patterson og Winston, 2009; van Dierendonck, Stam, Boersma, de Windt og Alkema, 2014). Prátt fyrir tengsl pjónandi forystu við ýmsar hug- 
myndir innan stjórnunar og forystu benda fræðimenn á sérstöðu og gildi pjónandi forystu sem hugmyndafræði samskipta, stjórnunar og forystu (Prosser, 2010; Sigrún Gunnarsdóttir, 2011). Rannsóknir sýna að sem hugmyndafræði nýtist pjónandi forysta í tengslum við stefnu, skipulag, aðgerðir og forgangsröðun innan skipulagsheilda (Laub, 2010). Til dæmis nýtist hugmyndafræðin í tengslum við stefnumiðaða mannauðsstjórnun eins og Cladwell, Trunon, Linh og Tuan (2011) benda á og leggja par sérstaka áherslu á mikilvægi siðfræðivíddar pjónandi forystu fyrir árangursríka mannauðsstjórnun. Siðfræðileg gildi eru ein af grunnstoðum pjónandi forystu (Greenleaf, 2008) og rannsóknir hafa ítrekað bent á vægi siðfræði og sameiginlegrar ábyrgðarskyldu í pjónandi forystu (Ragnarsson, Kristjánsdóttir og Gunnarsdóttir, 2018) sem og hlutverk gilda, tilgangs og stefnu í pjónandi forystu sem markar einnig árangur skipulagsheilda (Blanchard, 2018).

\subsection{2 Árangur af pjónandi forystu í fyrirtækjum}

Árangur pjónandi forystu samkvæmt nýjum rannsóknum snýr meðal annars að starfsánægju og betri líðan starfsmanna, hollustu starfsmanna, eflingu starfsmanna, skuldbindingu við fyrirtækið, betri frammistöðu, meiri árangri af teymisvinnu og traust til yfirmanna (Coetzer o.fl., 2017; Parris og Peachey, 2013; van Dierendonck, 2011). Finnsk rannsókn (Harju, Schaufeli og Hakanen, 2018) sýnir að aukið vægi pjónandi forystu í fari næsta y firmanns er jákvætt og marktækt tengt meiri ánægju í starfi. Pá hafa rannsóknir sýnt tengsl milli starfsánægju og hæfileika leiðtogans til að vera jafningi (Jenkins og Stewart, 2010) og hæfni leiðtogans í pví að sýna auðmýkt í samskiptum (Hayes og Comer, 2010). Ný rannsókn Sousa og van Dierendonck (2015) varpar ljósi á samspil auðmýktar og stefnumiðaðra aðgerða í pjónandi forystu og hvernig petta samspil tengist áhuga og virkni starfsfólks. Rannsóknir hér á landi sýna sambærilegar niðurstöður um tengsl pjónandi forystu og ánægju starfsfólks (Sigrún Gunnarsdóttir og Birna Gerður Jónsdóttir, 2013; Guðjón Ingi Guðjónsson og Sigrún Gunnarsdóttir, 2015; Sólveig Reynisdóttir og Sigrún Gunnarsdóttir, 2015). Rannsóknir um tengsl pjónandi forystu og vellíðan starfsfólks eru í takt við rannsóknir um tengsl styðjandi og hvetjandi forystu og góðrar heilsu og ánægju starfsfólks (Akerjordet, Furunes og Haver, 2018). Pá hafa rannsóknir gefið sterkar vísbendingar um jákvæð og marktæk tengsl milli pjónandi forystu og góðrar andlegrar líðan starfsmanna til dæmis meðal bankastarfsmanna í Pýskalandi (Rivkin, Diestel og Schmidt, 2014) og bankastarfmanna á Nýja Sjálandi (Babakus, Yavas og Ashill, 2011) sem og hjá sölumönnum í spænskum fyrirtækjum (Bande, Fernández-Ferrín, Varela og Jaramillo, 2015). Rannsóknir gefa einnig vísbendingar um að pjónandi forysta tengist frammistöðu par sem pjónandi forysta tengist sjálfstæði, umboði til athafna, að hæfileikar og kunnátta fái að njóta sín og um góð tengsl á vinnustað (Chiniara og Bentein, 2016; Panaccio, Henderson, Liden, Wayne og Cao, 2015; Ozyilmaz og Cicek, 2015) par sem pjónandi forysta tengist skuldbindingu starfsmanna og framtakssemi og pá er lykilatriði að sálfræðilegi samningurinn sé uppfylltur með nálgun pjónandi forystu. Pá hefur hollusta og tryggð starfsmanna verið könnuð í tengslum við pjónandi forystu og rannsóknir frá ýmsum löndum sýna að pjónandi forysta getur styrkt starfsmenn til að skuldbinda sig frekar fyrirtækinu (Alexandrov, Babakus og Yavas, 2007; Bono, Holdes, Vinson og Muros, 2007; Mulki, Jaramillo, og Locander, 2006; Kiggwe, 2011; Jaramillo, Grisaffe, Chonko og Roberts, 2009; Babakus, Yavas og Ashill, 2011; Kashyap og Rangnekar, 2016).

Prátt fyrir að fjöldi rannsókna um pjónandi forystu undanfarin ár hafi styrkt verulega fræðilegan bakgrunn hugmyndafræðinnar og gildi hennar liggja fyrir fáar rannsóknir sem varpa ljósi á viðhorf og reynslu stjórnenda í fyrirtækjum sem náð hafa afgerandi góðum árangri. Í ljósi pessa er áhugavert að fá innsýn í sjónarmið og áherslur stjórnendur hjá fyrirtækjum sem náð hafa sérstaklega góðum árangri. 


\section{Aðferðafræði}

\subsection{Eigindleg viðtalsrannsókn}

Eigindleg rannsóknaraðferð var nýtt til að kanna áherslur stjórnenda og leiðtoga sem starfa í fyrirtækjum sem náð hafa sérstaklega góðum árangri. Aðferðin hentar vel til að kanna og fá djúpa innsýn í einstaka reynslu og viðhorf sem fáar rannóknir hafa fjallað um. Rannsóknarferli Vancouver-skólans var haft til hliðsjónar með áherslu á að vera kyrr, að ígrunda, að koma auga á, að velja, að túlka, að raða saman og að sannreyna (Sigríður Halldórsdóttir, 2013). Notuð voru hálf opin viðtöl par sem spurningar voru að einhverju leyti ákveðnar fyrirfram en bætt við spurningum eftir pví sem viðtal próaðist til að kanna ný sjónarmið og til að kafa dýpra í efnið. Með pessum hætti voru könnuð persónuleg viðhorf viðmælenda, upplifanir peirra, reynslu og sérpekking á pví sviði sem er til rannsóknar. Pannig má einnig laða fram upplýsingar sem annars myndu jafnvel ekki koma fram (Helga Jónsdóttir, 2013). Leitast var við að hafa spurningar sem allra minnst leiðandi til að pær hefðu ekki áhrif á svör viðmælenda og að peir fengju að tjá reynslu sína og pekkingu og meðvitað ekki tiltekið í viðtölunum að niðurstöður greiningar gagna yrðu skoðaðar í ljósi hugmyndafræði pjónandi forystu. Ákveðið var að leita pátttakenda í hópi stjórnenda fyrirtækja á lista Fyrirmyndarfyrirtækja VR enda um að ræða fyrirtæki sem náð hafa sérstaklega góðum árangri samkvæmt könnunum par um (VR, 2016b).

\subsubsection{Fyrirmyndarfyrirtæki Verzlunarmannafélags Reykjavíkur (VR)}

Við val á pátttakendum í rannsóknina var litið til árangursríkra fyrirtækja samkvæmt árlegri könnun Verzlunarmannafélags Reykjavíkur (VR) um Fyrirtæki ársins. Könnunin er lögð fyrir félagsmenn VR par sem fyrir liggja fjölmargar spurningar par sem starfsmenn fyrirtækja meta nokkra lykilpætti í sínu vinnuumhverfi og leitað er svara við spurningum er varða ánægju peirra í starfi, upplifun hvað varðar virðingu fyrir einstaklingnum og framlagi á vinnustað. Fyrsta könnunin var gerð árið 1999 og markmiðið að hvetja fyrirtæki til að skapa starfsmönnum góð kjör og opna málefnalega umræðu um kjör félagsmanna VR („Ingvar Helgason“, 1996). Meginpættir könnunarinnar snúa að stjórnendum, trúverðugleika peirra og framkomu við starfsfólk. Pá er spurt um starfsanda og samskipti á milli starfsmanna, launakjör, vinnuskilyrði og aðstæður á vinnustað. Einnig er spurt um sveigjanleika á vinnutíma, sjálfstæði í starfi og áhrif starfsmanna á starf sitt sem og ánægju og stolt starfsmanna af vinnustað sínum og ímynd fyrirtækisins út á við (Steinunn Böðvarsdóttir, munnleg heimild 12. febrúar 2016). Árlega eru birtar niðurstöður könnunarinnar sem gefa mikilvæga innsýn í árangursríka pætti fyrirtækja sem skara fram úr hvað ánægju starfsmanna snertir (VR, 2016b).

Pegar spurningar í könnun VR (VR, 2016a) eru skoðaðar í samanburði við lykilpætti pjónandi forystu samkvæmt rannsóknum par um (Sigrún Gunnarsdóttir og Birna Gerður Jónsdóttir, 2013; van Dierendonck og Nuijten, 2010) koma í ljós nokkrir sambærilegir præðir svo sem efling, sjálfstæði starfsfólks, að stjórnandi forgangsraði í págu starfsfólks, ábyrgðarskylda og falsleysi. Samanburðurinn sýnir einnig að nokkrir meginpættir pjónandi forystu eru ekki til grundvallar könnun VR, til dæmis fyrirgefning, hugrekki, auðmýkt og samfélagsleg ábyrgð. Könnun VR nær jafnframt yfir pætti sem eiga ekki við um algeng mælitæki pjónandi forystu svo um launakjör, vinnuskilyrði, sveigjanleika í vinnu, stolt og ímynd fyrirtækis.

\subsubsection{Dátttakendur}

Notast var við tilgangsúrtak (e. purposive sampling) og fyrir val á pátttakendum var farið yfir lista Fyrirmyndarfyrirtækja hjá VR 5 ár aftur í tímann og leitast við að fá fulltrúa beirra sem voru oftar en einu sinni í 10 efstu sætum listans. Tekin voru viðtöl við sjö leiðtoga og stiórnendur fyrirtækja sem hlotið hafa titilinn Fyrirmyndarfyrirtæki VR á undanförnum árum. Viðmælendur tóku beiðni um viðtal vel, pekktu vel til lista VR um fyrirmyndar- 
fyrirtæki og voru mjög fúsir að ræða um áherslur sínar í stjórnun og forystu. Viðmælendur starfa hjá fyrirtækjum sem eru ólík að stærð og tilheyra mismunandi viðskiptasviðum, p.e. upplýsingatæknipjónusta og sala á tölvubúnaði, öryggispjónusta, snyrtivöruheildverslun, heildverslun með rafmagnsvörur, ráðgjafapjónusta, ferðaskrifstofa og verslunarfyrirtæki. Taka skal fram að ekkert pessara fyrirtækja hefur pjónandi forystu í stefnu sinni.

Nýrra viðmælenda var leitað par til mettun var komin í gögnin (Green og Thorogood, 2004). Viðmælendur voru mjög áhugasamir um efnið og veittu góðar upplýsingar um viðhorf sín og reynslu. Eftir fimmta og sjötta viðtalið voru komin fram gögn sem gáfu góða og djúpa mynd af rannsóknarviðfangsefninu og komin mettun í gögnin, p.e. ekki komu fram ný sjónarmið eða upplýsingar sem bættu við pau gögn sem voru komu fram pá pegar miðað við tilgang rannsóknarinnar (O’Reilly og Parker, 2007). Pess vegna var metið að fullnægjandi væri fyrir gæði rannsóknarinnar og fyrir djúpan skilning á viðfangsefninu að taka viðtöl við sjö viðmælendur. Gagnasöfnun fór fram árið 2016, hófst í febrúar og lauk í maí.

\subsubsection{Greining gagna}

Hvert viðtal var hljóðritað, ritað upp orðrétt og síðan formlega greint með kóðun, texta var raðað saman og leitast við að finna meginhugtök sem lýsa áherslum viðmælenda. Pá voru dregin fram ákveðin pemu sem voru lýsandi fyrir viðfangsefnið (Bryman og Bell, 2007; Sigríður Halldórsdóttir, 2013). Textinn var pví næst ritaður upp í samræmi við flokkun texta og gerð á honum samantekt par sem öll meginatriði komu fram og samantektin send hverjum viðmælanda og óskað eftir athugasemdum. Engin athugasemd var gerð við textann. Fundinn var rauður práður í gegnum öll viðtölin með pví að lesa pau vel yfir, ígrunda og raða texta saman eftir pemum og undirpemum. Að lokum voru niðurstöður fengnar og pær bornar saman við rituðu viðtölin til að gæta samræmis á milli rannsóknargagna og niðurstaðna og að gæta pess að öll pemu kæmu fram. Textinn sem hafði verið pemagreindur og flokkaður úr öllum viðtölum var prentaður út. Hann var klipptur niður og honum raðað saman eftir hverju yfirpema og undirpema og ritaður upp inn í niðurstöðukafla. Til að styrkja gæði rannsóknarinnar og áreiðanleika niðurstaðna var lögð áhersla á vönduð vinnubrögð í allri rannsóknarvinnu. Vandvirkni var gætt við undirbúning og framkvæmd viðtala, áhersla á nákvæmni við ritun viðtala, alúð lögð við öll stig greiningar gagna, meginatriði hvers viðtals voru borin undir viðkomandi viðmælanda og pess gætt að raddir allra viðmælenda kæmu fram pannig að reynsla allra pátttakenda skini í gegn (Sigríður Halldórsdóttir og Sigurlína Davíðsdóttir, 2013).

\subsubsection{Siðfræðileg álitamál}

Pátttakendur undirrituðu upplýst sampykki um pátttöku. Engum viðkvæmum persónulegum upplýsingum var safnað. Viðmælendum var kunnugt um að peim var heimilt að draga framlag sitt til baka á hvaða tímapunkti sem var sem og að neita að svara spurningum án frekari skýringa en til pess kom pó ekki.

\section{Niðurstöður}

Pegar kannaðar voru áherslur leiðtoga fyrirmyndarfyrirtækja og hvort pær endurspegluðu hugmyndafræði pjónandi forystu án pess að pað væri sérstaklega tiltekið við öflun gagna pá leiddi pað af sér prjú meginpemu sem lýst verður nánar hér á eftir. Fyrsta pemað er stjórnun sem stuðningur og samspil ólíkra hlutverka, annað pemað er hagur starfsmanna og jafningjatengsl leiðtoga og starfsmanna og priðja pemað er framtíðarsýn og virk upplýsingagjöf.

\subsection{Stjórnun sem stuðningur og samspil ólíkra hlutverka}

petta pema snýr aðallega að stjórnendum sjálfum og peirra pætti í samspili peirra við starfsmenn til að skapa góðan vinnustað og stuðla að fyrirmyndarfyrirtæki. Pessi páttur hefur prjú undirpemu sem öll lýsa áherslum viðmælenda hvað góða stjórnendur snertir. 
Viðmælendum og fyrirtækjum eru hér gefin ný nöfn með skammstöfunum V1, V2 o.s.frv. og F1, F2 o.s.frv.

\subsubsection{Djónustustuhlutverk, pjálfun og stuðningur}

Aðspurðir um hlutverk og eiginleika góðra leiðtoga höfðu nokkrir viðmælenda orð á pví að leiðtogar hafi mikil áhrif á vinnustaðinn og pví mikilsvert að peir séu hæfir til að gegna leiðtogastöðu og að sinna margpættu hlutverki. Fram kemur að viðmælendur líta á stjórnun sem pjónustuhlutverk, pjálfun og stuðning par sem leiðtoginn gegnir margskonar hlutverkum og skapar samspil ólíkra hlutverka og aðferða eftir aðstæðum hverju sinni. Stuðningur við sjálfa sig er einnig mikilvægt verkefni fyrir leiðtoga. Leiðtogi parf að vera sanngjarn og gefa ákveðið frelsi en vera á sama tíma fastur fyrir og hafa gott utanumhald um hlutina. Hann parf að vera til staðar án pess að pvælast fyrir. Fljótur að taka ákvörðun og standa við hana en að sama skapi að geta hlustað á rök annarra og skipt um skoðun ef pannig ber undir. Hann parf að vera mannpekkjari og koma auga á styrkleika og veikleika fólks og raða réttu fólki í hverja stöðu og laða fram pað besta frá hverjum starfsmanni og ná pannig meiri árangri. Hann parf að hafa skýra hlutverkaskiptingu, veita leiðsögn og vinna með sínu fólki að lausn verkefna og gæta pess að allir hafi sama skilning á verkefninu.

Að sögn V1 hafði staðan í mannauðsmálum F1 verið í lægð um ákveðinn tíma og til að auka ánægju starfsmanna var sett fram aðgerðaráætlun sem fólst meðal annars í pví að mæta pörfum starfsmanna. Aðgerðirnar voru af ýmsum toga en par á meðal var að efla stjórnendur með markvissum og mælanlegum hætti. Stjórnendur voru sendir til markpjálfa til að fá stuðning við að framkvæma nauðsynlegar breytingar og hafði pað afar mikil áhrif. V1 lítur á hlutverk leiðtoga sem pjálfara sem alltaf parf að hafa besta liðið á vellinum og pjálfi peir ekki fólkið sitt nái peir ekki árangri. Hún segir:

\section{Stjórnandi parfauk pess að byggja upp fólkið sitt og lyfta pví upp. Hugsa má fólkið eins og verðbréf, hann parf að auka virði peirra. Dví verðmeira sem fólkið er poí meiri árangri nærðu. Dví betur sem pú styður fólkið pitt pví meira lyftist pað upp og pannig lyftist stjórnandinn upp með pví.}

V5 segir stjórnun vera pjónustuhlutverk og pað sé leiðtogans að „hjálpa fólki pannig að umhverfið sé rétt til pess að pað geti náð árangri í sínum störfum . Ég vil leggja mitt af mörkum til pess að fólk geti náð árangri í pví sem pað parf að gera." Viðmælendur segja leiðtoga purfa að meta aðstæður hverju sinni. Stundum purfi hann að hlusta, stundum að tala, stundum að stýra og stundum að styðja en fyrst og síðast purfa leiðtogar að bera hag sinna starfsmanna fyrir brjósti.

\subsubsection{Auðmýkt og jafnvægi leiðtoga}

Úr viðtölum við flesta viðmælendur má greina ákveðna áherslu á mikilvægi auðmýktar í leiðtogahlutverki. Leiðtogi parf að vera mannlegur og leyfa öðrum að sjá mistök sín og læra af peim. Leiðtoginn parf að hrósa og gefa endurgjöf en ekki síður að kalla eftir endurgjöf og gagnrýni sjálfur. Leiðtoginn má ekki setja sig á háan stall og reyna heldur ekki að vera félagi allra og fórna pannig fagmennsku. V7 segir:
Durfum við ekki öll að vera svona pokkalega kurteis og almennileg og ekki hrokafull. Við erum náttúrulega bara hluti af heild og erum öll jafn mikilvæg. [...] Detta er ekki einræði heldur samvinna og pað verða allir að vera með alveg sama hvaða titil peir hafa. Engin keðja er sterkari en veikasti hlekkurinn. Hver einasti starfsmaður er hlekkur á keðjunni.

Einnig segir hann pað vera lykilatriði að leiðtogar pekki veikleika sína. Peir purfi að geta tekið gagnrýni og endurskoðað afstöðu sína, peir séu mannlegir en ekki alvitrir og óskeik- 
ulir. V4 er á sama máli og segir leiðtoga purfa að vera fljóta til ákvarðanatöku en mikilvægt sé að peir hlusti á hugmyndir annarra og hafi hugrekki til að skipta um skoðun hafi peir góð rök fyrir pví. Fyrir leiðtoga er nauðsynlegt að átta sig á pví að peir ná aldrei fullkomnun. Stöðugt purfi að læra nýja hluti, aðlagast breytingum og hlusta á aðra. Haldi menn að peir viti allt og geti allt pá ættu peir að hætta strax.

Aðspurðir um hvort peir geri eitthvað til að styrkja sjálfa sig sem leiðtoga sögðust flestir sækja sér fræðslu af ýmsu tagi, fara á ráðstefnur eða stunda nám tengt vinnu sinni. Pá halda sumir góðum tengslum við vini og kunningja sem gegna leiðtogastöðum og miðla ráðum og reynslu sín á milli. Nokkrir töluðu um að leiðtogar fyrirtækja peirra stunduðu markpjálfun og sögðu pað hafa gefið gríðarlega góða raun og veitt mikinn stuðning við erfiðar ákvarðanir og verkefni. Lögð var áhersla á mikilvægi hreyfingar til að styrkja sjálfan sig og vera meðvitaður um heilbrigðan lífsstíl. Pegar leiðtogi er í góðu jafnvægi hefur pað áhrif á starfsmenn og öfugt og segir V3: „pú parft að vera meðvitaður um að pú ert mikið betri stjórnandi ef pú ert sterkur, ferð í ræktina, borðar hollan mat og ert góð fyrirmynd“. Аð sögn V4 getur góð hreyfing skerpt hugann og haft mikil áhrif pegar menn sitja uppi með erfið mál sem peir hafa ekki náð að leysa. Pá segir V5 mikilvægt að hlúa að sjálfum sér í heild sem persónu og manneskju og stundar hún hugleiðslu og núvitund. Hún segir hver og einn purfa að sinna mörgum hlutverkum í lífinu og verði að vera ákveðið jafnvægi par á milli. Pá gerir hún reglulega ákveðið stöðumat á sjálfri sér hvað gildismat snertir og á sínum stjórnendaferli hefur hún purft að taka ákvörðun um að segja upp starfi sínu vegna pess að verkefnin voru í mótsögn við hennar gildismat.

\subsection{Hagur starfsmanna og jafningjatengsl leiðtoga og starfsmanna}

Annað meginpema snýr að sambandi leiðtoga og starfsmanna og hvernig góðir leiðtogar ættu að nálgast starfsmenn sína og bera hag peirra fyrir brjósti.

\subsubsection{Jafningjagrunnur}

Ákveðinn samhljómur var hjá viðmælendum um jafningjagrunn innan fyrirtækja peirra og voru peir einhuga um mikilvægi pess að starfsmenn hafi gott aðgengi að sínum leiðtoga. Tveir viðmælendur frá fyrirtækjum með yfir 100 starfsmenn sögðu að prátt fyrir stærð fyrirtækjanna væri ekki stórfyrirtækjabragur í menningu peirra heldur frekar reynt að halda í góð tengsl eins og í minni fyrirtækjum. Par af leiðandi sé nándin á milli starfsmanna og yfirmanna meiri. Hurðin inn til yfirmanna sé alltaf opin og pangað streymi starfsmenn með hugmyndir eða annað sem peir vilja ræða við forstjórann. Leiðtogar taki einnig virkan pátt í verkefnavinnunni og gagnkvæm virðing sé lykilatriði. Viðmælendur sögðu pað hlutverk leiðtoga að halda utan um hlutina en peir séu samt sem áður jafningjar starfsmanna. V7 nefndi að innan hans fyrirtækis væru starfsmenn með áratuga starfsreynslu og hefðu pví mikla pekkingu á starfi sínu. Peir viti pví oft meira um hlutina en hann sjálfur og taki hann mark á pví sem peir hafa að segja. Lögð var áhersla á teymisvinnu hjá flestum viðmælenda par sem allir vinna saman að pví að leysa verkefnin. Reglulega er farið yfir hvernig gengur, samskiptin eru á jafningjagrunni og leiðtogar noti ekki boðvald. Allir viðmælendur lögðu áherslu á sýnileika leiðtogans og að starfsmenn viti að peir geti alltaf leitað til hans. V7 sagði:

Ég reyni að láta sjá mig svona prisvar í viku [á öllum starfsstöðvum - innskot höfundar] að minnsta kosti. Maður fer bara að spjalla við fólkið og heyrir í pví, hvernig gengur og hoað er í gangi. Eg held að við séum svona bara ein stór fjölskylda að mörgu leyti.

\subsubsection{Hlustun og traust}

Viðmælendur sögðu pað lykilatriði að traust ríki í samskiptum leiðtoga og starfsmanna og purfi leiðtogi að vera góður hlustandi. V2: „Við erum með tvö eyru og einn munn pann- 
ig að við purfum að hlusta meira heldur en við tölum“. Sögðu peir mikilvægt að hlusta á starfsmenn til að ávinna traust peirra. Starfsmenn verði að finna að peir hafi rödd, að framlag peirra skipti máli og peir geti haft áhrif. Náist að skapa pannig menningu er fyrirtækið með starfsmenn sem vinna pví í hag og finna leiðir til að leysa öll vandamál. Treysti starfsmenn stjórnendum í erfiðum ákvarðanatökum verða allar ákvarðanir auðveldar í innleiðingu. V4 segir:

Degar starfsmaður virkilega finnur að pú gefur honum tíma til að koma sínum málefnum á framfxri pá skapast ákveðið traust á milli starfsmanns og fyrirtækisins. [...] Góð hlustun og dínamíkin sem getur skapast á bak við pað hún getur verið miklu meira en einn plús einn. [...] Pegar starfsmaður finnur að pað er hlustað á pað sem hann er að segja og brugðist við poí pað eru ómetanlegar stundir.

V2 sagði mikilvægt að leiðtogar hlusti á hugmyndir starfsmanna pví peir komi með mikið af góðum hugmyndum og fengju pær ekki hljómgrunn kæmi pað niður á allri starfsemi fyrirtækisins. Að mati V1 má helst ávinna traust starfsmanna með pví að leyfa peim að spreyta sig og taka pátt í ákvarðanatökum. Pá sögðu viðmælendur best að ávinna traust með góðum vinnubrögðum, samskiptum, framkomu og að vera samkvæmur sjálfum sér og standa við gefin loforð. V6 sagði fyrirtæki peirra byggjast á samvinnu og að reynt væri að virkja alla starfsmenn í pekkingarleit og nýsköpun og pau bæti hvort annað upp. V5 segir að hjá F5 fái starfsmenn að hafa áhrif og sé pað hvatning fyrir hvern og einn að vita hvernig hann tengist árangri fyrirtækisins. Fólk hafi skýra sýn á markmiðin og leggur hún áherslu á að starfsmenn viti hvað peir geti gert til að hafa sem mest áhrif á að sameiginlegum árangri sé náð:

Ég held að árangurinn hér felist í poí að hver einasti starfsmaður finnur að hann skiptir máli. Hann hefur sitt vægi i keðju fyrirtækisins i að skapa virði fyrir fyrirtækið, hann getur haft áhrif á pað á hvernig vinnustað hann vinnur og allar raddir heyrast mjög vel.

Í samtali við nokkra viðmælendur kom einnig fram áhersla peirra á að hlusta eftir og pekkja viðhorf starfsmanna til vinnustaðarins til að auka starfsánægju og vinna að úrbótum í mannauðsmálum. Рað sem hafði meðal annars mikil áhrif á bætt viðhorf starfsmanna til fyrirtækisins hjá F1 voru reglulegar starfsmannakannanir sem framkvæmdar voru til að kanna líðan og hug starfsmanna til vinnustaðarins. Haldnir voru fundir á hverju sviði með stjórnendum pess og starfsmönnum par sem niðurstöður voru kynntar og rætt pað sem vel var gert og hvað betur mætti fara. Mikilvægt var að leyfa starfsmönnum að tjá hug sinn og koma skoðunum sínum á framfæri. Unnið var markvisst að úrbótum og eru umbætur í mannauðsmálum í stöðugu ferli.

Hjá F6 er einnig mikil áhersla lögð á að starfsmenn fái að tjá hugmyndir sínar og heldur hver stjórnandi meðal annars vikulega fundi með sínu teymi par sem starfsmenn fá færi á að tjá sig. V6 segir: „pað er grundvallaratriði að fá input frá starfsmönnum frekar en að hugmyndir og skipanir komi eingöngu ofan frá“. Eftir mikla stækkun fyrirtækisins var stöðugt reynt að finna nýjar leiðir til að halda í tjáningafrelsið. Fyrirtækið kaupir pjónustu sérfræðinga til að framkvæma árlega tvær sérsniðnar viðhorfskannanir starfsmanna fyrir utan könnun VR. Á sérstökum upplýsingafundum með hverju teymi fyrir sig er farið yfir niðurstöður með starfsmönnum án stjórnenda til að fá opnar og heiðarlegar skoðanir og gagnlegar ábendingar um pað hvernig bæta má ferla, stjórnendur og vinnustaðinn yfir höfuð. Mörgum af hugmyndum starfsmanna hefur svo verið hrint 1 framkvæmd enda komi peir yfirleitt með snilldarhugmyndir. Pá segir V6 að pátttaka starfsmanna í að móta fyrirtækið og hafa áhrif í allri starfsemi pess sé helsta ástæðan fyrir jákvæðu viðhorfi starfsmanna til fyrirtækisins. 
V4 talar um að hjá F4 hafi verið farið í miklar endurbætur í mannauðsmálum eftir efnahagshrunið 2008 og sé pað helsta ástæðan fyrir jákvæðu viðhorfi starfsmanna til fyrirtækisins sem hefur haldið pví á lista fyrirmyndarfyrirtækja undanfarin ár. Ráðast purfti í mikinn kostnaðarniðurskurð í kjölfar hrunsins og var helmingi starfsmanna sagt upp störfum:

๖аð var einhugur um pað hér hjá stjórnendum og eigendum félagsins að gera eitthvað sérstakt fyrir starfsfólkið. Við vorum búnir að segja upp helmingnum af fyrirtækinu eða 60 manns af 120. Við hugsuðum, ok hvernig getum við gert petta pannig að peir sem eftir standa finni pað að peir hafi pennan stuðning og pað sé vel hlúð að peim. Pá stofnuðum við pennan ágæta umbótahóp sem var pannig að pað var svona miðlxgur vettvangur par sem fólk gat komið með ábendingar um pað sem pað vildi láta laga eða var miður eða jafnvel eitthvað bara sem var gott.

Pá fóru að sögn V4 allar ábendingar starfsmanna fyrir fund, pau rædd og öllum fyrirspurnum var svarað undir eins. Starfsmenn sáu að stjórnendur létu verkin tala hvað velferð peirra og líðan snerti. Að sögn V4 áttu starfsmenn stóran pátt í að gera gott fyrirtæki betra og standi fyrirtækið algjörlega á bak við starfsfólk sitt.

\subsubsection{Rými fyrir opin samskipti}

Í umræðum við viðmælendur var lögð áhersla á að byggja upp góð samskipti á vinnustað og viðhalda peim. V1 sagði:

Opin og regluleg samskipti eru nauðsynleg. Mistök eru leyfð. Við lærum af mistökum en ekkert svona „blamegame”. Alltaf pegar eitthvað kemur uppá, bara ræða pað. Ef starfsmenn finna að pað sé verið að ráðast á pá pegar einhver mistök verða pá fer fólk að missa frumkvæði sitt. Dað tekur ekki áhættu eða gerir mistök og segir kannski síđur frá poí.

Viðmælendur voru á einu máli um að komi upp vandamál eða erfiðleikar tengt samskiptum eða öðru sé best að leysa úr málum strax og pau verða. Mikilvægt sé að hafa samskiptin opin, skýr, hispurslaus og heiðarleg. Oft byggist samskiptaörðugleikar á misskilningi og til að leysa pá er best að ræða við viðkomandi undir eins til að koma í veg fyrir að valda meiri skaða og allir fái að tjá sína skoðun eða upplifun. V1 sagði að ef upp komi erfið starfsmannamál sé fyrirtækið með ákveðin ferli en nái vandamálið út fyrir getu mannauðsstjóra sé leitað til ákveðinnar sérfræðiaðstoðar til að leysa pað. Aðrir viðmælendur sögðust einnig leita til fagaðila eftir aðstoð í pannig kringumstæðum.

Starfsmannasamtöl hjá F2 fara fram árlega en par fyrir utan ræðir V2 við hvern starfsmann prisvar sinnum á ári par sem peim er gefið tækifæri á að ræða málin í einrúmi og sé pað gert í vinsemd. V5 segir svipaða sögu:

Dað parf að búa til rými fyrir samtal. Maður getur verið allur af vilja gerður en svo er maður alltaf á fundum eða bara praktískt séð ekki aðgengilegur. Pað parf að tryggja að pað sé alltaf rými til að eiga opin og regluleg samskipti. Taka á öllum málum strax pannig að pað sé ekkert sem fxr að gerjast. [Stjórnendur eiga - innskot höfundar] að sýna gott fordæmi i pví að samskipti skipta máli, pað verður að tala um hlutina og allt á að vera uppá borđum.

\subsubsection{Sjálfstæði og að vaxa í starfi}

Pegar rætt var um úthlutun verkefna og eftirfylgni komu fram áherslur viðmælenda á sjálfstæði starfsmanna í starfi og hvernig stjórnendur stuðla að pví sjálfstæði með hvatningu, leiðsögn og trausti til sinna starfsmanna. Ekki séu taldar unnar mínútur, leiðtogar gefi svigrúm og treysti starfsmönnum en eru alltaf til staðar til að leiðbeina og styðja. 
Mistök eigi að vera leyfð og pau löguð án pess að fundinn sé sökudólgur fyrir peim. Mikilvægt er að setja kröfur um góð vinnubrögð pannig að verkin uppfylli pann staðal sem peim er ætlað en veita starfsmönnum að sama skapi ákveðið frelsi til athafna og treysta peim. Að sögn V7 fær fólkið að ráða verkum sínum að töluverðu leyti án pess að hann andi ofan í hálsmálið á peim pó hann sem stjórnandi leggi línurnar: „,aðalmálið er að gefa fólkinu frjálsar hendur og að раð finni að pað skipti máli og hafi eitthvað um hlutina að segja“. Pá segir V4:

๖að er mjög mikilvægt fyrir okkur að búa pannig um hnútana að fólk læri sem mest og verði sem mest sjálfstæðast og sé sem lengst [...] pað skiptir okkur öllu máli að fólk geti verið sjálfstætt. Dað er forgangsatriði númer eitt.

Pá lögðu nokkrir viðmælenda áherslu á að veita starfsmönnum færi til starfspróunar innan peirra fyrirtækja. Innan F2 er mikið lagt upp úr eflingu starfsmanna til próunar í starfi. Peir sem hafa byrjað á gólfinu hafa fengið að vinna sig upp í stærri verkefni og jafnvel komist í deildarstjórastöðu. Fyrirtækið leigir til sín starfsmannastjóra nokkra daga í mánuði og eitt af hans verkefnum er að mennta upp bestu starfsmennina í hverri deild. Pað ferli tekur um pað bil eitt ár og er mikil styrking fyrir viðkomandi starfsmenn sem í kjölfarið fá betri stöðu innan fyrirtækisins. Mikið er lagt uppúr innri starfspróun hjá F1 að sögn V1 og mikilvægt að starfsmenn finni að yfirmenn vilji hjálpa peim að vaxa í starfi. Pegar hún er spurð um sínar helstu áherslur í stjórnun segir V1:

Dað er að lyfta fólki upp á næsta plan, fá pað til að verða hæfara og pað gefur mér sjálfri mjög mikið. Við erum með einn forstöðumann í vinnu núna sem kom inn og byrjaði á pjónustuborði og var mjög efnileg. Hún er búin að vaxa og vaxa. Ég hef sérstaklega verið að styðja við bakið á henni og hún var gerð að forstöðumanni.

[...] Dað er ótrúlega gaman að sjá pað, pað er eins og sjá barnið sitt stækka.

Í ráðningarsamningum F1 er getið um pekkingaröflun og að hún sé á ábyrgð bæði stjórnanda og starfsmanns að sögn V1 og geti starfsmenn alltaf sótt um að fara á námskeið sem eru fyrirtækinu og starfsmanninum í hag. Við ráðningu nýrra starfsmanna, sérstaklega peirra sem eru ungir að árum, er möguleg vegferð peirra innan fyrirtækisins teiknuð upp frá pví peir hefja störf og sýnt fram á hvaða leiðir peir hafi til að vaxa í starfi. V4 leggur einnig mikið uppúr pví að starfsmenn fái tækifæri til starfspróunar. Hafa peir kost á að sækja námskeið en auk pess veitir hann sínu fólki ýmsar áskoranir til að vaxa í starfi.

\subsubsection{Gott umherfi á vinnustað}

Allir viðmælendur lögðu ríka áherslu á að starfsmönnum líði vel í vinnunni og að komið sé til móts við parfir peirra og hugað vel að aðbúnaði peirra á vinnustað enda hefur pað mjög jákvæð áhrif á starfsmenn pegar hlúð er að umhverfi peirra. Рað sem meðal annars var mikill áhrifavaldur á starfsanda og jók til muna starfsánægju í F1, meira en nokkur átti von á, voru umbætur á húsnæði fyrirtækisins. V1 segir:

Við vorum í lélegu húsnæði og pað var allt tekið í gegn. Allt gert fint og góð aðstaða. Sá munur hafði miklu jákvæðari áhrif en við áttum von á og pað var svona „breakthrough" myndi ég segja i okkar tilfelli að fara svona hátt upp í könnun VR. Maður vissi að umhverfi og aðstæður skiptu máli en petta var miklu meira en við áttum von á.

Mötuneyti fyrirtækisins var einnig bætt og tekin ákvörðun um að allir starfsmenn fengju GSM-síma og vakti pað mikla lukku. Pá var gömul hefði innan fyrirtækisins endurvakin, ef áætlun fyrirtækisins stenst pá er árshátíð starfsfólks haldin erlendis annað hvert ár. 
Spurður um hvað í stjórnun F2 hafi skapað jákvætt viðhorf starfsmanna til fyrirtækisins segir V2 pað helst vera góðan starfsanda og skemmtilegt starfsumhverfi. Рað sé líka mjög gaman í vinnunni par sem til staðar sé ýmis afpreying fyrir starfsfólk eins og til dæmis poolborð, risasjónvarpsskjár, aðgangur að golfvöllum út um allt land og alls kyns uppákomur sem starfsmannafélagið stendur fyrir. Almennt sé gaman í vinnunni, fólki líði vel og reyni fyrirtækið að gera sitt besta hvað pað varðar.

Hjá F4 er ekki síður lögð áhersla á að mæta pörfum starfsmanna en viðskiptavina og sífellt reynt að koma með skemmtilegar hugmyndir hvað pá snertir. Á hverjum degi er boðið uppá ýmsar veitingar og eitthvað skemmtilegt gert til að stuðla að jákvæðu viðhorfi innan fyrirtækisins sem smitar svo út til viðskiptavina. Starfsmannaaðstaðan er góð par sem ýmis afpreying er í boði og hægt að setjast niður og eiga góða samveru. Pegar vel gengur fá starfsmenn að njóta pess og annað hvert ár er peim boðið til útlanda og greiðir fyrirtækið allan kostnað vegna árshátíða auk pess sem haldin eru óvænt partý og gefnar gjafir við ýmis tækifæri. Segir V4 pennan góða aðbúnað og skemmtilegt andrúmsloft meðal annars hafa skapað góða ímynd starfsmanna á fyrirtækinu.

\subsection{Framtíðarsýn og virk upplýsingagjöf}

Priðja meginpema snýr að mikilvægi pess að stjórnendur hafi skýra framtíðarsýn og að peir miðli henni ásamt öðrum upplýsingum er varðar starfsemi fyrirtækisins til starfsmanna.

Viðmælendur lögðu áherslu á virka upplýsingagjöf og gagnsæi í starfsemi fyrirtækisins. Sumir sögðu upplýsingagjöf vera í stöðugri vinnslu og er hún ein af helstu áherslum innan fyrirtækja nokkurra viðmælenda. Hjá F7 eru starfsmenn vel upplýstir um hvað framundan er í starfsemi fyrirtækisins og pekkja t.d. sölutölur og markaðsaðgerðir. Hjá F5 hafa starfsmenn aðgang að upplýsingum um fjárhag fyrirtækisins og geta jafnvel fylgst með í hvað fjármunum er varið. I gagnsæu umhverfi par sem starfsmenn hafa allar upplýsingar og vita hvernig reksturinn gengur taka peir ábyrgar ákvarðanir segir V5.

Viðmælendur nefndu mikilvægi pess að stjórnendur hefðu skýra sýn til framtíðar. Fyrirtæki purfi að hafa ákveðinn tilgang og til að ná árangri parf að setja fram skýr og mælanleg markmið. Viðmælandi sem starfar innan ráðgjafarfyrirtækis sagði:

\section{Við purfum alltaf að hafa okkar skýru stefnu pannig að fólk hérna viti hvert við erum að fara [...] pað má ekki vera neinn vafi á hvert er okkar hlutverk og til- gangur eða hvaða árangri við ætlum að ná. Dað i sjálfu sér er bara hvati til pess að allir vilji fara í vinnuna á morgnana.}

Fylgt er skýrri aðferðafræði við innleiðingu stefnu innan fyrirtækis V5. Hvert teymi setur sér skýr markmið og hver einstaklingur setur sér sínar skuldbindingar í hverri viku. Hver og einn metur hvað hann purfi að gera til að hreyfa við mælikvörðum fyrirtækisins. V7 sagði stjórnendur leggja línur til framtíðar og deildarstjórar setji fram markmið fyrir sínar starfsstöðvar í samráði við starfsmenn. Pegar áætlanir eru fullmótaðar eru allir sáttir og sammála um að vinna að peim markmiðum og hver starfsmaður veit hver stefnan er. Segja viðmælendur mikilvægt að starfsmenn taki pátt í að móta markmið og framtíðarsýn fyrirtækisins. Innan fyrirtækja par sem mikill vöxtur á sér stað parf að takast á við breytingarnar, ekki gleyma sér í vextinum og vaxa bara til að vaxa eða græða peninga. Við pannig aðstæður er mikilvægt að endurskoða stefnuna reglulega.

\section{Umræður}

Af niðurstöðunum má sjá að stjórnendur sem rætt var við og starfa í Fyrirmyndarfyrirtækjum VR bera hag starfsmanna sérstaklega fyrir brjósti. Viðmælendur leggja áherslu á stuðning til starfsmanna, sjálfstæði og vöxt peirra í starfi, jafningjabrag, auðmýkt, skýra framtíðarsýn og virkt upplýsingaflæði. Pessar áherslur koma að hluta til ekki á óvart 
pegar litið er til rannsókna um mikilvæga pætti leiðtoga sem tengjast vellíðan og ánægju starfsamanna (Alimo-Metcalfe, Alban-Metcalfe, Bradley, Mariathasan og Samele, 2008; Akerjordet, Furunes og Haver, 2018). Áherslur pátttakenda eru einnig í takt við rannsóknir um pætti sem tengjast ánægju nýrrar kynslóðar (Clifton, 2016). Áherslur stjórnendanna eru í takt við grunnviðmið stefnumiðaðrar mannauðstjórnunar um skipulag og aðgerðir (Cladwell, Trunon, Linh og Tuan, 2011). Pá endurspegla áherslurnar sem fram koma marga af meginpáttum í könnun um Fyrirmyndarfyrirtæki VR (Steinunn Böðvarsdóttir, munnleg heimild 12. febrúar 2016). Athygli vekur að niðurstöðurnar varpa einnig ljósi á áherslur pátttakenda sem ekki eru í forgrunni könnunar VR og má par einkum nefna áherslu á jafningjabrag innan fyrirtækjanna og auðmýkt leiðtoga (Hayes og Comer, 2010).

Pegar niðurstöðurnar eru skoðaðar í ljósi pjónandi forystu sést að pær endurspegla meginpætti hugmyndafræðinnar. Viðmælendur leggja allir áherslu á að veita starfsfólki sínu stuðning og um leið að vera föst fyrir, mæta starfsfólki á jafningjagrunni og halda vel utan um hlutina, veita starfsfólki tækifæri til vaxtar og hafa skýra stefnu. Petta samspil endurspeglar grunnpætti pjónandi forystu, p.e. hið samtvinnaða hlutverk, að vera samtímis pjónn og leiðtogi (Greenleaf, 2008). Að mati viðmælenda er mikilvægt að leiðtoginn gefi starfsfólki ákveðið frelsi en sé jafnframt fastur fyrir, að leiðtoginn sé til staðar fyrir starfsfólk en gætir pess að pvælast ekki fyrir, leiðtoginn parf að vera fljótur að taka ákvörðun og sömuleiðis að vera viðbúnn að hlusta á rök og skipta um skoðun. Petta samspil ólíkra hlutverka sem stjórnendur Fyrirmyndarfyrirtækja VR lýsa er í takt við eitt megineinkenni pjónandi forystu, að leiðtoginn er fremstur meðal jafningja (Greenleaf, 2008; Jenkins og Stewart, 2010) og skapar jafnvægi pjónustu og forystu (Coetzer o.fl., 2017; Blanchard, 2018; van Dierendonck, 2011).

Niðurstaðan um endurspeglun pjónandi forystu í orðum viðmælenda kemur ekki að öllu leyti á óvart enda er samsvörun með mörgum páttum sem eru til grundvallar viðurkenningu um Fyrirmyndarfyrirtæki VR og megineinkennum pjónandi forystu. Pessir sameiginlegu pættir eru einkum efling og sjálfræði starfsfólks, að forgangsraða í págu starfsmanna, ábyrgðarskylda og falsleysi (Steinunn Böðvarsdóttir, munnleg heimild 12. febrúar 2016; van Dierendonck, 2011). Pættir sem koma fram í niðurstöðunum og tilheyra pjónandi forystu en eru ekki til grundvallar könnun VR, svo sem jafningjabragur og auðmýkt, renna enn styrkari stoðum undir að áherslur stjórnenda Fyrirmyndarfyrirtækja VR endurspegla hugmyndafræði pjónandi forystu. Hér á eftir verður nánar fjallað um niðurstöður rannsóknarinnar og pær speglaðar í fyrri rannsóknum um pjónandi forystu.

Einlægur áhugi viðmælenda á hag starfsmanna kemur skýrt fram og orð peirra bera pess merki að peir leggi sig sérstaklega fram um að mæta pörfum peirra. Pátttakendur leggja ríka áherslu á eflingu starfsmanna og sýna niðurstöður íslenskra rannsókna um pjónandi forystu að efling næsta yfirmanns hefur sterka fylgni við starfsánægju (Sólveig Reynisdóttir og Sigrún Gunnarsdóttir, 2015; Guðjón Ingi Guðjónsson og Sigrún Gunnarsdóttir, 2014). Viðmælendur segja mikilvægt að starfsmenn finni að peir hafi rödd, að hugmyndir peirra skipti máli og að peir hafi áhrif á sínum vinnustað. Rannsóknir sýna að hlustun og hugmyndaauðgi hefur marktækt jákvæð tengsl við eflingu og skilar sér í meiri ánægju og tryggð starfsmanna (Men og Stacks, 2013). Meðal aðferða sem viðmælendur nýta sér eru ýmsar kannanir og nafnlausar ábendingar og hugmyndir starfsmanna til að gera úrbætur á vinnustaðnum og viðhalda starfsánægju. Eitt aðaleinkenni pjónandi leiðtoga er að hann ber umhyggju fyrir velferð fylgjenda sinna og sýnir hugmyndum peirra áhuga sem lýsir sér í góðri hlustun og felur í sér viðurkenningu á frelsi einstaklingsins (Sigrún Gunnarsdóttir, 2011).

Greina má sterka áherslu viðmælenda á að eiga opin samskipti á jafningjagrunni og að skapa rými fyrir regluleg samskipti stjórnenda og starfsmanna. Rannsóknir hafa sýnt að með jafningjabrag skapa pjónandi leiðtogar vinnustaðamenningu sem styður við opin samskipti (Belias og Koustelios, 2014), eflir starfsánægju (Jenkins og Stewart, 2010; Laub, 2010) og rennir stoðum undir auðmýkt í samskiptum (Hayes og Comer, 2010). Áherslur 
stjórnendanna sem tóku pátt í rannsókninni eru í takt við niðurstöður Hayes og Comer (2010) sem gefa vísbendingar um að auðmjúkir stjórnendur ávinni sér traust og virðingu og uppskeri meðal annars meiri ánægju sinna fylgjenda.

Frelsi til athafna og tækifæri til að vaxa i starfi

Viðmælendur töldu lykilatriði að efla starfsmenn með pví að veita peim frelsi til athafna og sjálfstæði í störfum sínum. Sýnt er að pegar starfsmenn fá meira umboð til athafna og vald til ákvarðanatöku leiðir pað til betri árangurs (Chiniara og Bentein, 2016) og starfsánægju (Men og Stacks, 2013). Viðmælendur eiga pað líka sameiginlegt að efla starfsmenn með pví að veita peim tækifæri til starfspróunar og vaxtar í starfi sem samræmist markmiðum pjónandi forystu um að frelsi, sjálfstæði og proska starfsfólks (Greenleaf, 2008). Rannsóknir hafa sýnt að tækifæri til að vaxa og ná árangri er liður í pví að mæta væntingum starfsmanna (Panaccio, Henderson, Liden, Wayne og Cao, 2015) og stuðla að ánægju starfsfólks og árangri (Coetzer o.fl., 2017; van Dierendonck, 2011).

Jafnvxgi alúdar og aga, stefnufestu og sveigjanleika

Úr niðurstöðum má greina sterka áherslu viðmælenda á skýra framtíðarsýn, tilgang og markmið og að hver og einn viti að hvaða árangri stefnt sé með skýrum skilaboðum og virkri upplýsingagjöf. Petta er í takt við niðurstöður rannsókna um pjónandi forystu sem sýna að skýr markmið og aðgengi að upplýsingum tengjast hvatningu og ánægju starfsfólks (Coetzer o.fl., 2017; Mishra, Boynton og Mishra, 2014). Skýr framtíðarsýn er ein af grunnstoðum pjónandi forystu og er samkvæmt Greenleaf (2008) forystupáttur hinnar samsettu hugmyndar sem vísar til aðgerðahluta hugmyndarinnar og framtíðarsýn er í raun forsenda pess að vera leiðtogi. Ný rannsókn Sousa og van Dierendonck (2017) sýnir hvernig aðgerðahluti pjónandi forystu í samspili við hinn mannlega hluta auðmýktar hefur afgerandi áhrif áhuga og virkni starfsmanna. Petta samspil grunnpátta pjónandi forystu sem tengist árangri fyrirtækja samkvæmt fyrri rannsóknum kemur fram hjá viðmælendum í rannsókninni gefur enn frekari innsýn í hvernig stjórnendurnir nýta mikilvægar stoðir pjónandi forystu. Af orðum viðmælenda má sjá að peir leggja áherslu á að vera til staðar en á móti vilja peir ekki pvælast of mikið fyrir; peir vilja vera fljótir að taka ákvörðun en á sama tíma leyfa starfsmönnum að hafa áhrif á ákvarðanatöku; peir raða fólki í hverja stöðu eftir getu peirra en gefa peim jafnframt tækifæri til að vaxa og próast í starfi og peir vilja beita aga en ekki síður vera sanngjarnir og gefa ákveðið frelsi.

\section{Áherslur pjónandi leiðtoga}

Af niðurstöðum rannsóknarinnar má sjá að stjórnendur sem pessi rannsókn nær til eru leiðtogar sem bera merki pjónandi forystu. Líklegt má telja að pær áherslur séu ómeðvitaðar að einhverju leyti, p.e. að ekki sé um formlegan ásetning að ræða að nýta hugmyndafræði pjónandi forystu. Pessar áherslur sem fram koma felast einkum í einlægum áhuga á hagsmunum og sjálfstæði starfsmanna, áherslu á jafningjagrunn og að efla eigin pekkingu og hæfni og skýrri framtíðarsýn sem allt eru pættir pjónandi forystu sem Robert Greenleaf (2008) og síðari tíma rannsakendur hafa lagt áherslu á.

Niðurstöður rannsóknarinnar varpa ljósi á að leiðtogar í Fyrirmyndarfyrirtækja VR sem tóku pátt í rannsókninni nýta aðferðir og áherslur sem samræmast niðurstöðum rannsókna um árangursríkar aðferðir fyrir ánægju og árangur starfsfólks. Prátt fyrir að mælikvarði fyrir mat á Fyrirmyndarfyrirtækjum VR eigi að ýmsu leyti margt sameiginlegt með hugmyndafræði pjónandi forystu vekur pað athygli hversu skýrt áherslur hugmyndafræðinnar koma fram í orðum viðmælenda og jafnframt að peir leggja áherslu á mikilvæga pætti pjónandi forystu sem ekki eru innan rammans um mat á Fyrirmyndarfyrirtækjum.

Rannsóknarniðurstöður gefa mynd af reynslu og viðhorfum viðmælenda en ekki er mögulegt að alhæfa niðurstöður yfir á stærri hóp. Fjöldi viðmælenda er takmarkaður í eigindlegum rannsóknum en leitast var við að tryggja gæði gagnaöflunar með pví að bæta 
við viðmælendum par til mettun var komin í gögnin (O’Reilly og Parker, 2007). Styrkur rannsóknarinnar felst meðal annars í pví að um er að ræða rannsóknarviðfangsefni sem snýr að fulltrúum fyrirtækja sem eiga skilgreinda pætti sameiginlega og viðmælendur höfðu mikinn áhuga á að ræða reynslu sína og viðhorf í tengslum við viðfangsefnið. Einnig styrkir pað rannsóknina að í viðtölunum komu fram djúp og greinagóð gögn og nákvæmni var gætt við greiningu gagna og framsetningu niðurstaðna.

Niðurstöður rannsóknarinnar veita innsýn í áherslur stjórnenda í fyrirtækjum sem skara fram úr varðandi árangur og ánægju starfsfólks. Slík innsýn er mikilvæg fyrir vellíðan starfsfólks og velgengni fyrirtækja ekki síst á tímum örra breytinga, vaxandi álags og hættu á preytu og vansæld í starfi (Gallup, 2016). Niðurstöðurnar eru framlag til próunar pekkingar, einkum á sviði pjónandi forystu. Rannsóknarniðurstöður geta nýst stjórnendum og starfsfólki fyrirtækja og stofnana og jafnframt eru pær áhugaverðar fyrir pá sem próa mælikvarða um árangursríka stjórnun og forystu fyrirtækja. Áhugavert er að rannsaka nánar viðhorf og reynslu starfsfólks og stjórnenda fyrirtækja sem ná góðum árangri, til dæmis með spurningalistakönnun og með hliðsjón af viðhorfum ungra starfsmanna.

\section{Lokaord}

Rannsóknin varpar nýju ljósi á reynslu og viðhorf stjórnenda sem hafa hlotið viðurkenningu fyrir sérstakan árangur. Stjórnendurnir sem rætt var við leggja áherslu á velferð starfsfólksins, sjálfstæði hvers og eins og að starfsfólk hafi tækifæri til að proskast og vaxa í starfi. Jafningjabragur í samskiptum stjórnenda og starfsmanna kemur fram sem mikilvægur páttur og pátttakendur lýsa hvernig peir flétta saman ólíka pætti til að skapa jafnvægi alúðar og aga, stefnufestu og sveigjanleika. Sjálfspekking er pátttakendum mikilvæg sem og samskipti sem einkennast af auðmýkt og skýrum línum um stefnu og hlutverk hvers og eins. Pessir pættir samrýmast rannsóknum sem lýsa árangursríkum áherslum fyrir vellíðan og velferð starfsfólks, ekki síst rannsóknum sem fjalla um tengsl pjónandi forystu og jákvæðrar útkomu fyrir starfsfólk og árangur starfa. Niðurstöðurnar gefa skýrar vísbendingar um að pátttakendur rannsóknarinnar bera með sér marga af lykilpáttum pjónandi leiðtoga.

\section{Heimildir}

Alexandrov, A., Babakus, E. og Yavas, U. (2007). The Effects of Perceived Management Concern for Frontline Employees and Customers on Turnover Intentions: Moderating Role of Employment Status. Journal of Service Research, 9(4), 356-371.

Alimo-Metcale, B., Alban-Metcalfe, J., Bradley, M., Mariathasan, J. og Samele, C. (2008). The impact of engaging leadership on performance, attitudes to work and wellbeing at work. Journal og Health Organization and Management, 22(6), 586-598.

Akerjordet, K., Furunes, T. og Haver, A. (2018). Health-promoting leadership: An integrative review and future research agenda. Wiley, 74, 1505-516.

Aronsson, G., Theorell, T., Grape, T., Hammerström, A., Hogstedt, C., Marteinsdottir, I., Skoog, I., Träskman-Bendz, L. og Hall, C. (2017). A systematic review including meta-analysis of work environment and burnout symptoms. BMC Public Health, 17(264), 1-13.

Babakus, E., Yavas, U. og Ashill, N. J. (2011). Service Worker Burnout and Turnover Intentions: Roles of Person-Job Fit, Servant Leadership, and Customer Orientation. Services Marketing Quarterly, 32(1), 17-31.

Bande, B., Fernández-Ferrín, P., Varela, J. A. og Jaramillo, F. (2015). Emotions and salesperson propensity to leave: The effects of emotional intelligence and resilience. Indurstrial Marketing Management, 44, 142-153.

Belias, D. og Koustelios, A. (2014). Organizational Culture and Job Satisfaction: A Review. International Review of Management and Marketing, 4(2), 132-149.

Blanchard, K. (2018). What is servant leadership? Í Blanchard, K. og Broadwell, R. (ritstjórar), Servant Leadership in Action: How You Can Achieve Great Relationships and Results (bls. 7-13). Kalifornía: Berrett-Koehler Publishers.

Bono, J. E., Foldes, J. H., Vinson, G. og Muros, H. P. (2007). Workplace Emotions: The Role of Supervision and Leadership. Journal of Applied Psychology, 92(5), 1357-1367.

Bryman, A. og Bell, E. (2007). Business Research Methods (2. útg.). Oxford: Oxford University Press. 
Chiniara, M. og Bentein, K. (2016). Linking servant leadership to individual performance: Differentiating the mediating role of autonomy, competence and relatedness need satisfaction. The Leadership Quarterly, 27(1), 124-141.

Caldwell, C., Truong, D. X., Pham T. Linh, P. T. og Anh Tuan, A. (2011). Strategic Human Resource Management as Ethical Stewardship. Journal of Business Ethics, 98(1), 171-182. DOI 10.1007/s10551-010-0541-y

Clifton, J. (2016). How Millennials want to work and live: The six big changes leaders have to make. Washington: Gallup.

Coetzer, M. F., Bussin, M. og Geldenhuys, M. (2017). The Functions of a Servant Leader. Administrative sciences, 7(5), 1-32.

Drucker, P. F. (1999). Management Challenges for the 21st Century. New York: Harper Business.

Gallup. (2016). The Worldwide Employee Engagement Crisis. Sótt 23. september 2018 af: https://www.gallup.com/ workplace/236495/worldwide-employee-engagement-crisis.aspx

Goleman, D. (1995). Emotional Intelligence. Why it can matter more than IQ. New York: Bantam Books.

Goleman, D. (2006). Social Intelligence. The New Science of Human Relationship. New York: Random House.

Goleman, D. (2013, desember). The Focused Leader. Harvard Business Review. Sótt af https://hbr.org/2013/12/ the-focused-leader

Green, J. og Thorogood, N. (2004). Qualitative Methods for Health Research. London: Sage.

Greenleaf, R. K. (2008). The Servant as Leader. Westfield: The Greenleaf Center for Servant Leadership.

Guðjón Ingi Guðjónsson og Sigrún Gunnarsdóttir. (2014). Pjónandi forysta og starfsánægja í Háskóla Íslands. Stjórnmál E stjórnsýsla, 10(2), 499-522.

Harju, L., Schaufeli, W. B. og Hakanen, J. J. (2018). A multilevel study on servant leadership, job boredom and job crafting. Journal of Managerial Psychology, 33(1), 2-14.

Hayes, M. A. og Comer, M. D. (2010). Start with humility. Lessons from America's quiet ceos on how to build trust and inspire followers. Westfield: Greenleaf Center for Servant Leadership.

Helga Jónsdóttir. (2013). Viðtöl í eigindlegum og megindlegum rannsóknum. Í Sigríður Halldórsdóttir (ritstjóri), Handbók i aðferðafræði rannsókna (bls. 137-153). Akureyri: Háskólinn á Akureyri.

Herzberg, F. (1987, september). One More Time: Hovy Do You Motivate Employees? Harvard Business Review. (Reprint 87507).

Ingvar Helgason hf. er fyrirtæki ársins '96. (1996, maí). VR blaðið, bls. 12-13.

Jaramillo, F., Grisaffe, D. B., Chonko, L. B. og Roberts, J. A. (2009). Examining the impact of servant leadership on salesperson's turnover intention. Journal of Personal Selling \& Sales Management, 29(4), 351-365.

Jenkins, M. og Stewart, A. C. (2010). The importance of a servant leader orientation. Health Care Management Review, 35(1), 46-54.

Kashyap, V. og Rangnekar, S. (2016). Servant leadership, employer brand perception, trust in leaders and turnover intentions: a sequential mediation model. Review of Managerial Science, 10(3), 437-461.

Kiggwe, M. (2011). Servant leadership and sales force performance in the banking sector of Uganda (óbirt doktorsritgerð). Makerere University.

Laub, J. A. (2010). The servant organization. Í D. Van Dierendonck og K. Patterson (ritstjórar), Servant leadership: Developments in theory and research (bls. 105-117). Hampshire: Palgrave Macmillan.

Liden, R. C., Wayne, S. J., Zhao, H. og Henderson, D. (2008). Servant leadership: Development of a multidimensional measure and multi-level assessment. The Leadership Quarterly, 19, 161-177.

Men, L. R. og Stacks, D. W. (2013). The impact of leadership style and employee empowerment on perceived organizational reputation. Journal of Communication Management, 17(2), 171-192.

Mishra, K., Boynton, L., og Mishra, A. (2014). Driving Employee Engagement: The Expanded Role of Internal Communications. International Journal og Business Communication, 51(2), 183-202.

Mulki, J. P., Jaramillo, F. og Locander, W. B. (2006). Emotional Exhaustion and Organizational Deviance: Can the Right Job and the Leader's Style Make a Difference? Journal of Business Research, 59(12), 1222-1230.

Ozyilmaz, A. og Cicek, S. S. (2015). How does servant leadership affect employee attitudes, behaviors, and psychological climates in a for-profit organizational context? Journal of Management E Organization, 21(3), 263-290.

O'Reilly, M. og Parker, N. (2007). 'Unsatisfactory Saturation': a critical exploration of the notion of saturated sample sizes in qualitative research. Qualitative Research, 13(2) 190-197.

Panaccio, A., Henderson, D. J., Liden, R. C., Wayne, S. J. og Cao, X. (2015). Toward an Understanding of When and Why Servant Leadership Accounts for Employee Extra-Role Behaviors. Journal of Business and Psychology, 30(4), 657-675.

Parolini, J., Patterson, K. og Winston, B. (2009). Distinguishing between transformational and servant leadership. Leadership \& Organization Development Journal, 30(3), 2, 274-291

Parris, D. L. og Peachey, J. W. (2013). A systematic literature review of servant leadership theory and organizational contexts. Journal of Business Ethics, 113(3), 377-393.

Prosser, S. (2010). Servant Leadership: More Philosophy, Less Theory. Westfield: The Greenleaf Center for Servant Leadership.

Ragnarsson, S., Kristjánsdóttir, E. og Gunnarsdóttir, S. (2018). To be accountable while showing care: The lived experience of people in a servant leadership organization. SAGE Open. DOI: 10.1177/2158244018801097. 
Rivkin, W., Diestel, S. og Schmidt, K.H. (2014). The positive relationship between servant leadership and employees' psychological health: A multi-method approach. German Journal of Research in Human Resource Management, 28(1-2), 52-72.

Sendjaya, S., Sarros, J. C. og Santora, J. C. (2008). Defining and Measuring Servant Leadership Behaviour in Organizations. Journal of Management Studies, 45(2), 402-424.

Sigríður Halldórsdóttir. (2013). Fyrirbærafræði sem rannsóknaraðferð. Í Sigríður Halldórsdóttir (ritstjóri), Handbók i aðferðafræði rannsókna (bls. 281-297). Akureyri: Háskólinn á Akureyri.

Sigríður Halldórsdóttir og Sigurlína Davíðsdóttir. (2013). Réttmæti og áreiðanleiki í megindlegum og eigindlegum rannsóknum. Í Sigríður Halldórsdóttir (ritstjóri), Handbók í aðferðafræði rannsókna (bls. 61-69). Akureyri: Háskólinn á Akureyri.

Sigrún Gunnarsdóttir. (2011). Pjónandi forysta. Fyrri hluti. Glíman, 8, 245-262.

Sigrún Gunnarsdóttir og Birna Gerður Jónsdóttir. (2013). Pjónandi forysta og rannsóknir hér á landi. Stjórnmál E stjórnsýsla, 9(2), 415-438.

Sólveig Reynisdóttir og Sigrún Gunnarsdóttir. (2015). Líðan pjónustustarfsmanna upplýsingatæknifyrirtækja og pjónandi forysta. Í Lára Jóhannsdóttir, Snjólfur Ólafsson og Sveinn Agnarsson (ritstjórar), Vorráđstefna Viðskiptafræðistofnunar (bls. 60-72). Reykjavík: Viðskiptafræðistofnun Háskóla Íslands.

Sousa, M og van Dierendonck, D (2017). Servant Leadership and the Effect of the Interaction Between Humility, Action, and Hierarchical Power on Follower Engagement. Bus Ethics 141(1), 13-25

van Dierendonck, D., Stam, D., Boersma, P., de Windt, N. og Alkema, J. (2014). Same difference? Exploring the differential mechanisms linking servant leadership and transformational leadership to follower outcomes. The Leadership Quarterly, 25, 544-562

van Dierendonck, D. (2011). Servant Leadership: A review and synthesis. Journal of Management, 37(4), 12281261.

van Dierendonck, D. og Nuijten, I. (2010). The Servant leadership survey: Development and validation of a multidimensional measure. Journal og business and psychology, 26(3), 249-267.

VR. (2016a). Helstu niðurstöður. Sótt 10. maí 2016 af http://www.vr.is/kannanir/fyrirtaeki-arsins-2015/helstunidurstodur/

VR. (2016b). Virðing á vinnustaðnum. Sótt 28. janúar 2016 af http://www.vr.is/kannanir/fyrirtaeki-arsins-2015/ virding-a-vinnustadnum/

Zwingmann, I., Wegge, J., Wolf, S., Rudolf, M., Schmidt, M. og Richter, P. (2014). Is transformational leadership healthy for employees? A multilevel analysis in 16 nations. German Journal of Research in Human Resource Management, 28(1-2), 24-51. 